\title{
Development of Water Recognition Skills Training Model in Children
}

\author{
Wendri Maryadi ${ }^{1}$, Achmad Sofyan Hanif $^{2}$, and Wahyuningtyas Puspitorini ${ }^{3}$ \\ ${ }^{1,2,3}$ Pendidikan Olahraga, Universitas Negeri Jakarta, Jakarta, Indonesia \\ ${ }^{*}$ Corresponding author. Email: maryadiwendri01@gmail.com
}

\begin{abstract}
Children who first practice swimming, must first be introduced to the properties of water. The introduction of water really needs to be applied to all those who want to learn swimming specifically for children with intellectual disabilities, of course it is very important to do water swallowing. The achievement of objectives in the training process cannot be separated from the role of the trainer in creating a harmonious training atmosphere in the training environment. The purpose of this study was to develop a water recognition exercise model for mentally retarded children. The development of this research refers to Borg and Gall. The subjects in this study were 42 students. Data collection techniques carried out by observation, study documentation, interviews, and tests. Data analysis was carried out qualitatively and quantitatively. The development of the model through small trials, large trials and effectiveness tests. Test the effectiveness of this water recognition model using the significance test Pre-test and Post-test significance test for differences with SPSS 25 in the results of $t$-count $=-28,971, d b=43$ and $p$-value $=0.00 \&$ lt; 0.05 which means that there are significant differences in the ability of students before and after being given a water recognition skills training model in mentally retarded children. In this study conclusions can be drawn. (1) Model of water recognition skills training exercises for mentally retarded children can be developed and applied in training mentally retarded children (2) Models of water recognition skills training exercises for mentally retarded children can effectively improve the water recognition abilities of mentally retarded children.
\end{abstract}

Keywords: Introduction of Water, Swimming, Mentally disabled

\section{INTRODUCTION}

Sport is a physical activity that is very popular in various circles of society. Regardless of status, gender, and age everyone can exercise. Sports are all systematic activities to encourage, foster, and develop physical, spiritual, and social potential [1]. As a form of physical activity, exercising can increase physical potential such as training the muscles of the body, as well as training the working system of the lungs and heart so that they can provide benefits in the form of physical fitness and health maintenance.

As has been explained, not only makes a healthy body condition, but by exercising can encourage someone to be able to achieve. Exercising can form social interaction and good character, by exercising can lead to a spirit of sportsmanship which means being willing to accept defeat, fair play, and foster a spirit of spirit that never gives up to continue to practice in improving physical condition. Through the deepening and mastery of the skills of one of the sports branches, it does not let go of the possibility of achieving desired achievements in the field of sports. Sports are based on the benefits of the sport itself, so that the understanding of sports can be understood with sports activities carried out by someone.
Various kinds of activities experienced by a person and calculated carefully are one way of learning the sport itself, this will lead to a variety of varied experiences of movement in his life [2].

Sport is also one of the entertainment for the lover because in sports other than cultivating the body or making the body healthy it also shows actions that pamper the eyes in an appearance that can be seen directly or through the media and even many people even misuse the function and purpose of the sport including in terms of the negative is that many also make sports a gambling ingredient. The lack of psychological research in the last few years has resulted in one's efforts in completing tasks, adding aspects to life for many years is a goal to motivate people. This is based on the goals and benefits of life and sports [3].

Children who first practice swimming, must first be introduced to the properties of water. When children already know the properties of water, surely the fear of water will disappear and confidence will grow. The introduction of water is very necessary for children who are just growing up and developing because in that phase the child is very fond of doing water activities both at home, swimming or on the beach, water recognition is 
very necessary to be applied to all those who want to learn swimming specifically in children mental retardation is certainly very important to do water swallowing.

Mental retardation is a condition of a child whose intelligence is far below average which is characterized by limited intelligence and inadequacy in social interactions. Mental retardation (MR) is a genetic disorder that is mainfested in significantly below average overall intellectual functioning and deficits in adaptive behavior [4].

Children with mental retardation or also known as mentally retarded because of the limitations of intelligence are difficult to follow education programs in ordinary schools classically, therefore mentally retarded children need special educational services, which is tailored to the child's ability. Diagnosing mental retardation in early childhood and identifying its causes might be helpful in reducing the frequency of this condition [5].

Water recognition training activities taught can be provided by modifying the training model, with a simple, usual context that is only done in an iterative manner which can certainly create a child's boredom. With this development through approaches such as play, media and so on, the introduction of water can be given by directing children to do well, creating a happy atmosphere, so that it can lead to children's motivation in following the exercise and can improve the water recognition skills needed. In connection with the use of media in learning activities, instructors or teachers need to be careful in the selection and or determination of the media to be used [6].

\section{REVIEW OF LITERATURE}

Water recognition sports are really needed by everyone, men, women, adults, children, teenagers and even parents, who still make sports that are water recognition with the aim of professional entertainment, fun, throwing away, bored always on land and dealing with several problem. Aquatic is an activity in the water with the aim of training children to advance their motor, cognitive, affection and social potential [7].

At all times, the introduction of water itself is a tool to provide ideas for learning to swim, and leads to the development of correct swimming techniques with an easy and appropriate range by means of basic training in water and is free, safe, enjoyable, beneficial, even there are exercises that make a big challenge, technical training is training to improve the movement techniques needed to be able to do sports that athletes do. Exercises must be in accordance with the conditions that are desired to be achieved with a simple program and do not make children quickly bored and shouldered when doing.
In conducting the pumping technique exercise, it is suggested that when applied to the athlete, the athletes should not use elite athletes models or examples, because their techniques may not physiologically meet biomechanical requirements, so here it is recommended to use models that are acceptable to athletes namely models the beomechanical and physiological suit of the athlete. The designs illustrate one approach to interactive training for a specific sport, and there are few frameworks or reviews reflecting across a range of examples [8].

Children with mental disabilities are a term used to refer to children who have intellectual abilities below average, in the literature of foreign languages used the terms mental retardation, mentally retarded, mental deficiency, mental defective, and others. In Indonesia mental retardation is called the weak mind, mentally retarded, stupid or stupid, pander, stupid, oligophrenic, able to educate, able to train, and full dependence.

Life below the average intellectual ability, weakness in adaptive attitudes, and have genetic disorders can be interpreted as mental retardation. The presence of signs in children with reduced intelligence and adaptability and experiencing abnormalities in growth in general is a definition of mental retardation [4]. Thestatement above states that mental retardation (MR) is caused by abnormalities in genetic have a significant effect on intellectual functioning below the average so that it affects the adaptive behavior of children. Mental retardation occurs in certain circumstances that begin in childhood and is characterized by a decrease in intelligence and adaptive skills and is also the most common developmental disorder.

Furthermore, according to Santrock that mental retardation is a condition with symptoms before the age of 18 years that involves low intelligence that is IQ under 70 and difficulty in adapting to daily life 5 [9]. This is reinforced by $\mathrm{R}$. Schalock, et al who said that "Intellectual disability is characterized by significant limitations both in intellectual functioning and in adaptive behavior as expressed in conceptual, social, and practical adaptive skills. This disability originates before age 18 "[10].

The statement above says that intellectual disability is characterized by significant limitations in both intellectual functioning and adaptive behavior as expressed in conceptual, social, and practical adaptive skills. This defect originates before age from some experts' opinions it can be concluded that, mentally retarded children are those whose intelligence is below normal average, difficult in adjusting to the environment, and less capable in thinking about abstract things so they find it difficult to follow the program classical school 
education. Therefore, they need special services and guidance tailored to the child's abilities.

Developmental impairment as a disorder that includes general intellectual functions below the average, namely IQ 84 and below based on tests and appears before the age of 16 years [11]. mentions that "mental retardation is closely related to the problem of developing low intelligence abilities and is a condition". Mental Retarded is not a disease but a condition" [12]. So, based on the above statement it can be confirmed that mental retardation is a condition that cannot be cured with any medicine.

\section{METHODOLOGY}

The purpose of this study was to develop a water recognition exercise model for mentally retarded children. The development of this research refers to Borg and Gall. The subjects in this study were 42 students. Data collection techniques carried out by observation, study documentation, interviews, and tests. Data analysis was carried out qualitatively and quantitatively. The development of the model through small trials, large trials and effectiveness tests.

\section{CONCLUSION}

From the results of the analysis as a preliminary study conducted by researchers on 20 to 24 July 2018 in several swimming clubs located in Jambi showed the following results, Criteria 8 trainers who train swimming included in the category enough, Criteria 1 trainers who train in training in swimming the category is lacking, Criteria 1 of the trainers who train in swimming training is categorized as very poor. Maximum ability of children with special needs has increased very slowly compared to others, or will not even experience it at all if it is not developed properly. We as academics can see the delay in achieving achievement in terms of chromosomes. If we can't see it from the chromosomes, we can see it since we are babies. Children who experience mental retardation can be caused by an injury that is experienced, the ability of the child will be easy or difficult or will not be mastered at all if not developed properly [13].

From the recapitulation results of a small-scale trial with a sample of 20, it can be concluded that the entire Water Introductory Skills Training Model for Children with Developmental Impairments Iq 50 - 70 can still be applied well and run smoothly and athletes feel happy even in the instructions of the trainer during training, athletes beginners feel satisfied with the playing model and the trainer can provide explicit and extensive material for new athletes, the results show that can be done at the large-scale trial stage. Mental health occurs how well an individual cope with his / her daily life and the challenges it brings, when an individual's mental health is poor it could be difficult to function in daily life. The pervasiveness of mental disability worldwide has generated a lot of debate over the actual meaning and the nature of the phenomenon [14].

From the results of the recapulation of a large-scale trial $(n=51)$ above, it can be said that the entire training material for the Water Introductory Skills Training Model for Children with intellectual Disabilities 50-70 can be accepted and implemented well and smoothly, novice athletes feel happy, satisfied, and get something new when doing the model in which the material is by instructor jambi.

\section{REFERENCES}

[1] Undang-Undang No. 23 tahun 2005. Sistem Keolahragaan Nasional.

[2] Seippel, "The meanings of sport: fun, health, beauty or community?," Sport Soc., vol. 9, no. 1, pp. 5170, 2006.

[3] T. Polson, "Effects of goal setting on performance in collegiate athletes," Skyline-The Big Sky Undergrad. J., vol. 1, no. 1, p. 9, 2013.

[4] V. Armatas, "Mental retardation: definitions, etiology, epidemiology and diagnosis," J. Sport Heal. Res., vol. 1, no. 2, pp. 112-122, 2009.

[5] M. Foroutan, "Mental Retardation (MR) Etiology in Children Referred to Care Services," J. Patient Saf. Qual. Improv., vol. 2, no. 4, pp. 165-167, 2014.

[6] Riyanto, P. (2016). Pengaruh pemanfaatan ilmu teknologi (audio visual) Terhadap motivasi belajar penidikan jasmani di SMP Negeri 1 Panjalu. Biormatika: Jurnal ilmiah fakultas keguruan dan ilmu pendidikan, 2(01)

[7] A. Z. Kusumaningrum, A. Kristiyanto, and S. Riyadi, "The Implementation of Swimming Games Learning for Pre-School Students in Singapore Piaget Academy," Int. J. Multicult. Multireligious Underst., vol. 6, no. 4, pp. 135-139, 2019.

[8] M. M. Jensen, M. K. Rasmussen, and K. Grønbæk, "Design sensitivities for interactive sport-training games," in Proceedings of the 2014 conference on Designing interactive systems, 2014, pp. 685-694.

[9] S. R. Yussen, J. W. Santrock, and J. Cracknell, Child development: An introduction. WC Brown Company, 1978.

[10] B. J. Silverstein, D. R. Olvera, and R. Schalock, "Allocating direct-care resources for treatment of maladaptive behavior: the Staff Intensity Scale," Ment. Retard., vol. 25, no. 2, p. 91, 1987.

[11] C. J. Fogelman, "American Association on Mental Deficiency (AAMD) Adaptive Behavior Scale, revision." Washington, DC: AAMD, 1975.

[12] S. Collins et al., "Liver-related deaths in persons infected with the human immunodeficiency virus: 
the D: A: D study," Arch. Intern. Med., vol. 166, no. 15, pp. 1632-1641, 2006.

[13] B. Onyekuru and J. Njoku, "Classroom management of mental retardation," Int. J. Learn. Dev., vol. 2, no. 5, pp. 105-111, 2012.

[14] T. B. E. Omorogiuwa, "The impacts of mental disability: implications for social work practice," African J. Soc. Work, vol. 7, no. 1, pp. 1-8, 2017. 